\title{
The Mechanical Properties of Granular Soils Injected by Silica Fume-Lime Mixtures
}

\author{
Ekrem Kalkan \\ Department of Civil Engineering \\ Engineering Faculty \\ Ataturk University \\ Erzurum, Turkey
}

\author{
Hamza Furkan Hartutlugil \\ Camborne School of Mines \\ Exeter University \\ Penryn, Cornwall \\ United Kingdom
}

\begin{abstract}
Soil In this study, granular soil material was stabilized by using injection method under laboratory conditions. As additive, the mixtures of silica fume and lime were used for this experimental study. The mixtures that are turned into slurries by adding water were injected to the granular soil media prepared in the cylindrical plastic mold. Then these samples were cured for 1, 7 and 28 days. The end of curing time, all samples were tested in accordance with unconfined compressive tests and obtained unconfined compressive strength values of injected granular soil samples were compared with that of the natural granular soil samples. As a result, it is concluded that the he mixtures of silica fume and lime can be successfully used for the improve of granular soils in the geotechnical applications.
\end{abstract}

Keywords: Granular soil, injection method, mechanical property, silica fume, lime

\section{INTRODUCTION}

World population growth of human is increasing day by day and the suitable soil to sustain loading from buildings or structure are becoming scarce. Due to the scarcity of land, the development of the swampy areas, mountainsides and landfill areas become the alternate places for the people to live. Hence, soil stabilization has become one of the useful solutions to treat the soil in such areas to achieve the required engineering properties and specification so that structures can be placed safely without undergoing large settlements (Kazemain and Barghchi, 2012).

The soil is one of the most important and primary media for any construction work. The strength and durability of any structure depends on the strength properties of soil (Nath et al., 2017). Soil stabilization is defined as a technique to improve the engineering characteristics in order to improve the parameters such as shear strength, compressibility, density, hydraulic conductivity. The techniques of soil stabilization can be classified into a number of categories such as vibration, surcharge load, structural reinforcement improvement by structural fill, admixtures, and grouting and other methods. There are many techniques that can be used for different purposes by enhancing some aspects of soil behavior and improve the strength and properties of soil (Edil, 2003; Kazemain and Barghchi, 2012).

The improvement of soil properties is necessary to solve many engineering problems. Soil improvement techniques can be classified in various ways, for example, mechanical, chemical, and physical stabilization (Ingles and Metcalf, 1977; Lambe and Whitman, 1979; Naeini and Mahdavi, 2009). In the mechanical stabilization, the soil density is increased by the application of mechanical forces in the case of surface layer compaction. Chemical stabilization includes incorporation of additives such as natural soils, industrial byproducts or waste materials, and cementitious and other chemicals. Physical stabilization includes changing the physical conditions of a soil by means of heating or freezing (Naeini and Sadjadi, 2008; Arab, 2019; Yarbaş1 and Kalkan, 2019; Yarbaş1 and Kalkan, 2020; Kalkan, 2019; Kalkan et al., 2020).
Improved performance of natural and crushed aggregate is often obtained by using additives such as cement, lime, zeolite, bentonite, bitumen, cement kiln dust, flue-gas desulphurization, pulverized fuel ash, granulated blast furnace slag, sodium silicates, sodium chloride or a combination of these materials (Mayers et al. 1976; Van Ree et al. 1992; Ahmed and Lovell 1993; Dawson et al. 1995; Baldwin et al. 1997; Muroueh et al. 2001; Edil, et al. 2002; Senol et al. 2003; Petkovic et al. 2004; Hassan et al. 2005; Senol et al. 2006).

Silica fume and fly ash are extensively used in geotechnical engineering applications. These materials have low unit weight, low compressibility and high pozzolanic reactivity (Cabrera and Gray 1973; Ravina 1980; Malhotra and Carette 1982; Aitcin et al. 1984; Ozbayoglu 1993; Kalkan et al. 2007). In particular, lime stabilisation has been used successfully in such geotechnical applications as foundations, capping, embankments, piles and other earthworks. (Locat et al. 1996; Cai et al. 2006; Kalkan, 2012; Kalkan, 2018; Aydin, 2019; Kalkan, 2020); Ozer and Bayrak, 2020.

The choice of technology and methods of the soil stabilization depends on the engineering challenges that determine the formulation of injection composition. A common method of soil stabilization is cementation using hydraulic fracturing of soil layers, where the use of compositions based on cement with various mineral and chemical additives is efficient. The dry mixture of injection composition depends on the types: of the used binder, chemical additives and mineral fillers. Highly effective binders in injection compositions are: aluminate, sulfo-aluminate, ferrite-containing, expansible lightweight, weighted, low hygroscopic and belite-diatomaceous earth oilwell cements (Kroychuk, 2005; Krivoborodov et al., 2009; Bazhenov et al., 2011; Chumakov, 2011). The cost of such cements is high and not all regions of the country have them. Interest is attracted by slag, ash and sand cements, the raw materials for which are the existing waste of the fuel and metallurgical complex and natural sand (Sergeev, 1984; Krivenko and Pushkareva, 2012; Marčiulatis et al., 2015; Mackevicius et al., 2017). The results of researches show that injection compositions based on such cements have a lower cost (Zhilkina et al., 2018). 
In this study the mixtures of silica fume and lime as alternative low-cost stabilizer material. The main objectives of this research are to investigate the utilizable of mixtures silica fume and lime as injection material for stabilization of granular soils in geotechnical applications. Also, to test mechanical performance of injected granular soils with mixtures silica fume and lime. The injected granular soils were subjected the unconfined compression tests and the results obtained were compared with that of natural granular soils.

\section{MATERIAL AND METHODS}

\subsection{Materials}

The granular soil material produced by grinding were selected for tests. This material obtained from limestone and crystallized limestone primary rocks were supplied from the Stone Quarry Facility of Makimsan Company in Erzurum, Turkey. The grain size distribution of the granular soil material was given in Figure 1. The soils had a density of 2.75 $\mathrm{Mg} / \mathrm{m}^{3}$

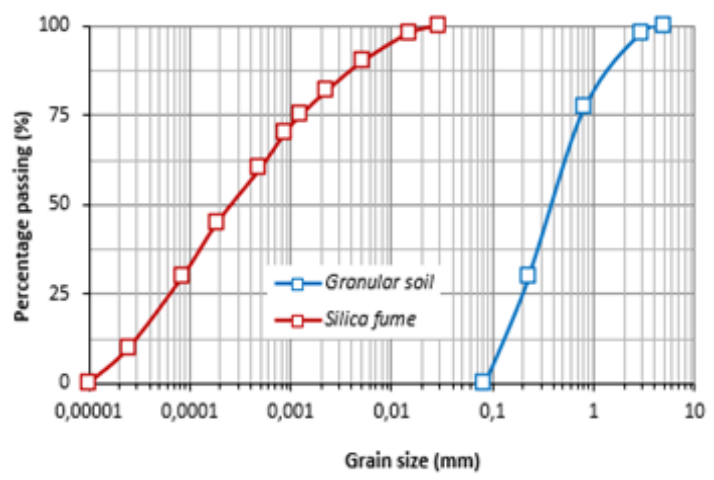

Figure 1. Grain size distribution of granular soil and silica fume

In this study, silica fume was used as waste material. The silica fume used in the tests was supplied from FerroChromate Factory in Antalya, Turkey. The density of silica fume is $2.0-2.5 \mathrm{Mg} / \mathrm{m}^{3}$, and the bulk density ranges from 0.3 to $0.5 \mathrm{Mg} / \mathrm{m}^{3}$. The grain size distribution of silica fume was given in the Figure 1.

The lime was used as manufactured additive material in this study. The lime used in tests was supplied from Kayseri Lime Factory in Kayseri, Turkey.

\subsection{Methods}

\subsubsection{Preparation of samples}

To obtain the unconfined compressive strength values, the cylindrical divisible plastic mold with the $35 \mathrm{~mm}$ diameter and $70 \mathrm{~mm}$ height. The granular soil material was placed in to this cylindrical plastic mold at the $50 \%$ relative density. The slurry was prepared by adding water to the mixture. The mixture was including $80 \%$ silica fume and $20 \%$ lime. The slurry was taken to the hand injector and then it injected to the granular soil media in the cylindrical plastic mold by manually (Figure 2).

The maximum care has been taken to ensure that the injection is fully spread into the granular soil media. After getting full injection, the injection process was finished and the injected samples were left for their curing process. The end of curing periods, the samples were subjected to the unconfined compressive tests.

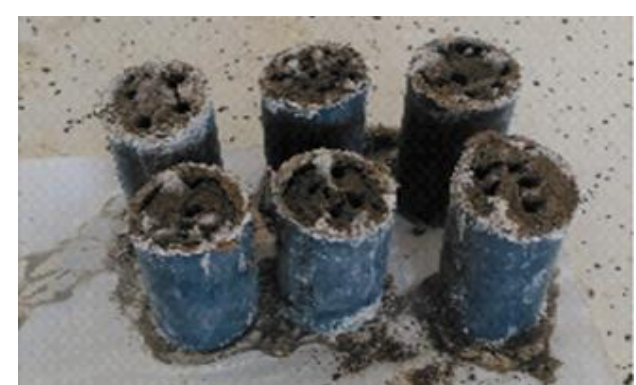

Figure 2. Injected granular soil samples

\subsubsection{Unconfined compression test}

The unconfined compressive strength values of natural and injected granular soil samples were determined from the unconfined compression test in accordance with ASTM D 2166. The unconfined compression test was carried out on the cylindrical samples. All of the samples had $35 \mathrm{~mm}$ in diameter by $70 \mathrm{~mm}$ in length. In this study, three cylindrical samples were prepared and tested for each combination of mixtures. The unconfined compression test was performed at a deformation rate of $0,8 \mathrm{~mm} / \mathrm{min}$. The natural and injected granular soil sample subjected to the unconfined compressive test and tested sample was given in Figure 3.

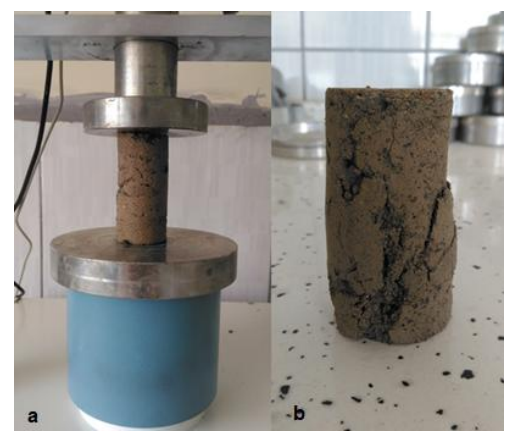

Figure 3. Injected granular soil samples; (a) under the unconfined compressive test and (b) after the unconfined compressive test

\section{RESULTS AND DISCUSSION}

\subsection{Effects of injection on the unconfined compressive strength values of granular soil samples}

The unconfined compression tests were performed to investigate the effect of injection on the unconfined compressive strength values of the granular soil samples. The unconfined compression tests were carried for the different curing periods. The results obtained from these tests were illustrated on the Figure 4. The test results showed that the injection of mixture with $80 \%$ silica fume and $20 \%$ lime improved the unconfined compressive strength values of granular soil samples. In the stabilization of the granular soil with injection of mixture with $80 \%$ silica fume and $20 \%$ lime, mixture played a significant role. The increase in the compressive strength was attributed to the internal friction of silica fume particles and the chemical reaction between silica fume and lime particles. In addition to being a highly pozzolanic material, the extremely fine silica fume particles improved the packing of the granular soil media, resulting in a denser stabilised soil (Glasser 1997; Neville and Aitcin 1998; Hassan et al. 2005; Kalkan 2006), increasing the cohesion 
(Kalkan and Akbulut 2004). The increase in the compressive strength is due to the hydration and hardening that occurred between the silica fume and lime particles, enhanced by the pozzolanic properties of the waste materials (Kohno et al. 1993; Temimi et al. 1998; Sebastia et al. 2003; Kalkan 2006; Kalkan, 2012).

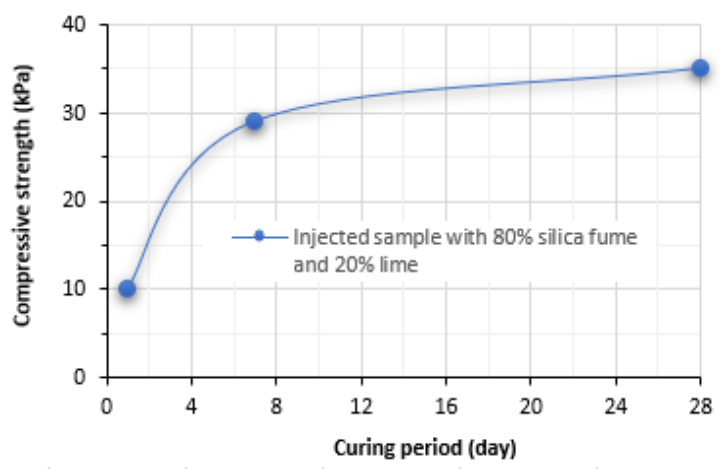

Figure 4. Effects of injection on the unconfined compressive strength values of granular soil samples

\subsection{Effects of curing period on the unconfined compressive strength values of injected granular soil samples}

The injected samples were cured for 1,7 and 28 days to investigate the effects of curing times on the unconfined compressive strength values. As seen in Fig. 4, curing period increases the compressive strength values. The same results were obtained by Thompson (1968), Okagbue and Onyeobi (1999), Yarbaş1 et al., 2007 and Kalkan (2012). The increase in the unconfined compressive strength with curing time is due to the action of the cementing gel materials of mixture of silica fume and lime produced following pozzolanic, hydration and chemical reactions.

\section{CONCLUSIONS}

In this study, the effects of mixture including silica fume and lime on the unconfined compressive strength values of injected granular soil samples. According to the test results, injection of mixtures of silica fume and lime improved the unconfined compressive strength of granular soils. Also, the curing time play a significant role on the improvement of mechanical properties of stabilized granular soil samples by injection method. As a result, the mixtures of silica fume and lime can be used as an injection material for the stabilization of the granular soils in the geotechnical applications.

\section{ACKNOWLEDGEMENTS}

This experimental research was supported by the Scientific Research Project of Ataturk University with the ID number of 2364 and code of PRJ-2016-210. So, the authors thank the authorities of the Ataturk University for the support.

\section{REFERENCES}

[1] Ahmed, I., Lovell, C.W., 1993. Use of waste materials in highway construction: state of the practice and evaluating of the selected waste product. Transportation Research Record, 1345, TRB, National Research Council, Washington, DC, pp 1-9.

[2] Aitcin, P.C., Ballivy, G., Parizeau, R., 1984. The use of condensed silica fume in grouting. Innovative cement grouting. Publication SP-83, ACI Detroit MI, USA, pp. $1-18$.
[3] Arab, M.G., 2019. Soil Stabilization Using Calcium Carbonate Precipitation via Urea Hydrolysis. Proceedings of the 4th World Congress on Civil, Structural, and Environmental Engineering (CSEE'19), April, 2019, Rome, Italy.

[4] Aydin, S., 2019. Determination of Prospective Science Teachers' knowledge levels about earthquake. International Journal of Earth Sciences Knowledge and Applications 1 (1), 28-31.

[5] Baldwin, G., Addis, R., Clark, J., Rosevear, A., 1997. Industrial byproducts in road construction-water quality effects. CIRIA Report 167. CIRIA, London.

[6] Bazhenov, Y.M., Korovyakov, V.F., Denisov, G.A., 2011. Technology of Dry Building Mixes: Study Guide, ACU, Moscow.

[7] Cabrera, J.K., Gray, M.M., 1973. Specific surface, pozzolanic activity and composition of pulverized fuel ash. Fuel Journal 52, 213-215.

[8] Cai, Y., Shi, B., Ng, C.W.W., Tang, C., 2006. Effects of polypropylene fiber and lime admixture on engineering properties of clayey soil. Engineering Geology 87, 230240.

[9] Edil, T.B., 2003. Recent advances in geotechnical characterization and construction over peat and organic soils" Proceedings $2^{\text {nd }}$ International Conference on Advances in Soft Soil Engineering and Technology. (Eds). Huat et al. Malaysia: Putrajaya, pp. 3-25.

[10] Dawson, A.R., Elliot R.C., Rowe G.M., Williams, J., 1995. An assessment of the suitability of some industrial by-products for use in pavement bases in the United Kingdom. Transport Research Record, No: 1486, pp 114123 .

[11] Edil, T.B., Benson, C.H., Bin-Shafique, M., Kim, W., Tanyu, B.F., Senol, A., 2002. Field evaluation of construction alternatives for roadway over soft subgrade. Journal of Transport Research Record 178, 36-48.

[12] Glasser, F.P, 1997. Fundamental aspects of cement solidification and stabilization. Journal of Hazardous Materials 52, 151-170.

[13] Hassan, H.F., Taha, R., Al Rawas, A., Al-Shandoudi, B., Al-Gheithi, K., Al-

[14] Barani, A.M., 2005. Potential uses of petroleumcontaminated soil in highway construction. Constructing and Building Materials 19, 646-652.

[15] Ingles, O.G, Metcalf, J.B., 1977. Soil Stabilization Principles and Practice. 2nd ed, Australia Butterworths.

[16] Kalkan, E., 2006. Utilization of red mud as a stabilization material for preparation of clay liners. Engineering Geology 87 (3-4), 220-229.

[17] Kalkan, E., 2012. Effects of waste material-lime additive mixtures on mechanical properties of granular soils. Bulletin of Engineering Geology and the Environment 71, 99-103.

[18] Kalkan, E., 2020. A Review on the Microbial Induced Carbonate Precipitation (MICP) for Soil Stabilization. International Journal of Earth Sciences Knowledge and Applications 2 (1), 38-47.

[19] Kalkan, E., Akbulut, S., 2004. The positive effects of silica fume on the permeability, swelling pressure and compressive strength of natural clay liners. Engineering Geology 73, 145-156. 
[20] Kalkan, E., Yarbaşı N, Akbulut, S., 2007. Use of solid waste-lime mixtures for soil improving. Symposium of Erdogan Yuzer Engineering Geology, 6-7 September 2007, ITU Mining Faculty, Istanbul, Turkey, pp 253-262.

[21] Kalkan, E., Yarbasi, N., Bilici, O., 2019. Strength performance of stabilized clayey soils with quartzite material. International Journal of Earth Sciences Knowledge and Applications 1 (1)1-5.

[22] Kalkan, E., Yarbaşı, N., Bilici, Ö., 2020. The Effects of Quartzite on the Swelling Behaviors of Compacted Clayey Soils. International Journal of Earth Sciences Knowledge and Applications 2 (2), 92-101.

[23] Kazemain, S., Barghchi, M., 2012. Review of soft soils stabilization by grouting and injection methods with different chemical binders. Scientific Research and Essays 7 (24), 2104-2111.

[24] Kohno, K., Amo K., Ogawa Y., Ikezoe, Y., 1993. Effect of admixture consisting of finely ground silica and red mud on properties of high strength concrete for products. In: Proceedings of the $4^{\text {th }}$ EASEC, Seoul, Korea, I, 1437.

[25] Krivoborodov, Y.R., Burlov, A.Y., Burlov, I.Y., 2009. The use of recoverable resources for cement production. Stroitel'nye Materialy, 2.

[26] Krivenko, P.V., Pushkareva, E.K., 2012. Cement and concretes based on ashes and slags, IPK ExpressPolygraph, Kiev.

[27] Kroychuk, L.A., 2005. Russian cement industry. Stroitel'nye Materialy 1.

[28] Kuznetsova, T.V., 2010. Production and application sulfoaluminate Cements. Stroitel’nye Materialy 3.

[29] Lambe, T.W., Whitman, R.V., 1979. Soil Mechanics. SI version, New York, Wiley.

[30] Locat, J., Tremblay, H., Leroueil, S., 1996. Mechanical and hydraulic behavior of a soft inorganic clay treated with lime. Canadian Geotechnical Journal 33, 654-669.

[31] Mackevicius, R., Slizyte, D., Zhilkina, T., 2017. Procedia Engineering 172, 681-684.

[32] Marčiulatis, V., Sližyte, D., Mackevičius, R., Zhilkina, T.A., 2015. Engineering Structures and Technologies 7(3), 140-145.

[33] Malhotra, V.M., Carette, G., 1982. Silica Fume Concrete, Properties, Applications, and Limitations. 10th Annual Meeting of the Institute of Concrete Technology, Slough, England, pp 1-23.

[34] Mayers, J.F., Pichumani, R., Kapples, B.S., 1976. Fly ash as a construction material for highways. U. S. Department of Tranportation Report No: FHWA-IP-7616 , Washington DC, USA.

[35] Muroueh, U., Eskola, P., Laine-Ylijoki, J., 2001. Lifecycle impacts of the use of industrial by-products in road and construction. Waste Manage 21:271-277.

[36] Nath, B.D., Molla, M.K.A., Sarkar, G., 2017. Study on Strength Behavior of Organic Soil Stabilized with Fly Ash. International Scholarly Research Notices 2017, 5786541

[37] Naeini, S.A., Mahdavi, A., 2009. Effect of polymer on shear strength of silty sand. EJGE 14, 1-11.

[38] Naeini, S.A., Sadjadi, S.M., 2008. Effect of Waste Polymer Materials on Shear Strength of Unsaturated Clays. EJGE 13, 1-12.
[39] Neville, A.M., Aitcin, P.C., 1998. High-performance concrete-an overview. Material Structure 31, 111-117.

[40] Okagbue, C.O., Onyeobi, T.U.S., 1999. Potential marble dust to stabilize red tropical soils for road construction. Engineering Geology 53, 371-380.

[41] Ozbayoglu, F.U., 1993. Usage of fly ashes with additive bentonite, lime and cement in stabilization of sandy soils. In: Symposium on the Usage of Industrial Wastes in Construction Areas, Ankara, 103-117.

[42] Ozer, C., Bayrak, E., 2020. Coulomb Stress Changes after 11 May 2017 Askale-Erzurum (NE Turkey) Earthquake $(\mathrm{Mw}=4.7)$. International Journal of Earth Sciences Knowledge and Applications 2 (1), 13-18.

[43] Ravina, D., 1980. Optimized determination of PFA fineness with reference to pozzolanic activity. Cement and Concrete Research 10, 573-580.

[44] Sebastia, M., Olmo, I.F., Irabien, A., 2003. Neural network prediction of unconfined compressive strength of coal ash-cement mixtures. Cement and Concrete Research 33, 1137-1146.

[45] Senol, A., Bin-Shafique, M., Edil, T.B., Benson, C.H., 2003. Use of Class $C$ fly ash for the stabilization of soft soil as subbase. ARI Bulletin of Istanbul Technical University 53, 89-95.

[46] Senol, A., Edil, T.B., Bin-Shafique, M., 2006. Soft subgrades' stabilization by using various fly ashes. Resour Conserv Recycling 46, 365-376.

[47] Sergeev, A.M., 1984. Use of Energy Industry Wastes in Construction Industry, Budivelnyk, Kiev.

[48] Temimi, M., Ben Amor, K., Camps, J.P., 1998. Making building products by extraction and cement stabilization: limits of the process with montmorillonite clay. Applied Clay Sciences 13, 245-253.

[49] Thompson, M.R., 1968. Lime treated soils for pavement construction. ASCE J. Highway Division 94 HW-2 5967.

[50] van Ree, C.C.D.F., Weststrate, F.A., Meskers, C.G., Bremmer, N.C., 1992. Design aspects and permeability testing of natural clay and sandbentonite liners. Geotechnique 42, 49-56.

[51] Yarbaş1, N., Kalkan E., 2019. The Stabilization of Sandy Soils by Using the Plastic Bottle Waste. International Journal of Advance Engineering and Research Development 6 (11), 140-144.

[52] Yarbaş1, N., Kalkan E., 2020. The Mechanical Performance of Clayey Soils Reinforced with Waste PET Fibers. International Journal of Earth Sciences Knowledge and Applications 2 (1) 19-26.

[53] Yarbaş1, N., Kalkan, E., Akbulut, S., 2007. Modification of the geotechnical properties, as influenced by freezethaw, of granular soils with waste additives. Cold Regions Science and Technology 48 (1), 44-54.

[54] Zhilkina, T., Sychugov, S., Gumeniuk, A., Mackevicius, R., Turchin, V., Vasilev, V., Zakirov, M., Ilinsky, A., 2018. Technology of soil stabilization with cementsand grouting mortar with optimal aggregate grading. MATEC Web of Conferences 193, 05046 (ESCI 2018). 